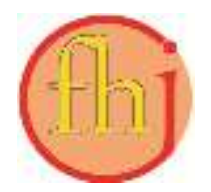

Faletehan Health Journal, 7 (3) (2020) 124-131

www. journal.Ippm-stikesfa.ac.id/ojs/index.php/FHJ

ISSN 2088-673X | e-ISSN 2597-8667

\title{
Faktor Risiko Terjadinya Obesitas Pada Remaja SMA
}

\author{
Imelda Telisa ${ }^{1 *}$, Yuli Hartati ${ }^{1}$, Arif Dwisetyo Haripamilu ${ }^{2}$ \\ ${ }^{1}$ Jurusan Gizi Poltekkes Kemenkes Palembang, Indonesia \\ ${ }^{2}$ Instalasi Gizi RSUP Dr. Mohammad Hoesin Palembang, Indonesia \\ *Corresponding Author: imeldatelisa@poltekkespalembang.ac.id
}

\begin{abstract}
Abstrak
Jumlah remaja dengan status gizi obesitas di Indonesia mengalami peningkatan dari tahun ke tahun. Faktor penyebab terjadinya obesitas pada remaja bersifat multifaktorial. Asupan zat gizi makro berlebih, peningkatan konsumsi fast food, kurangnya aktivitas fisik, faktor genetik, faktor psikologis, jumlah uang saku, pengaruh iklan, status sosial ekonomi, tidak sarapan pagi, usia, dan jenis kelamin merupakan faktor-faktor yang menyebabkan perubahan pola makan dan gaya hidup sehingga menyebabkan ketidakseimbangan energi dan berakibat pada risiko obesitas. Tujuan penelitian ini untuk mengetahui faktor-faktor risiko yang mempengaruhi terjadinya obesitas pada remaja. Penelitian ini bersifat observasional analitik dengan desain cross sectional. Sampel penelitian sebanyak 118 siswa kelas $\mathrm{X}$ dan $\mathrm{XI}$, yang dihitung dengan teknik proporsional stratified random sampling. Hasil uji statistik menunjukkan faktor yang secara signifikan berhubungan dan menjadi faktor risiko terjadinya obesitas pada remaja adalah asupan energi ( $p$-value $=0.000 ; \mathrm{OR}=2.97) ;$ protein $(p$-value $=0.005 ; \mathrm{OR}=3.49 ;$ lemak $(p$-value $=0.000 ; \mathrm{OR}=6.57)$; karbohidrat $(p$ value $=0.050 ; \mathrm{OR}=2.00)$; konsumsi fast food ( $p$-value = 0.000; OR = 4.41); aktivitas fisik ( $p$-value = 0.007; OR = 3.08); uang saku ( $p$-value $=0.032 ; \mathrm{OR}=2.38)$; dan keturunan ( $p$-value $=0.001 ; \mathrm{OR}=3.98)$. Remaja dengan asupan zat gizi makro berlebih, konsumsi fast food yang sering, aktivitas fisik rendah, uang saku tinggi dan memiliki riwayat orang tua yang gemuk, memiliki risiko lebih terhadap terjadinya obesitas.
\end{abstract}

Kata Kunci: Faktor Risiko, Obesitas, Remaja

\section{Risk Factors of Obesity among Adolescents in Senior High School}

\begin{abstract}
Adolescents with the nutritional status of obesity in Indonesia have increased in number each year. Factors causing obesity in adolescent is multifactorial. Excessive intake of macro-nutrient, increased consumption of fast food, lack of physical activity, genetic factors, psychological factors, the amount of pocket money, the influence of advertising, socioeconomic status, no breakfast, age, and gender are the factors of diet and lifestyle change. They may cause energy imbalance which results on obesity risk. The study aims to determine the factors that influence the risk of obesity in adolescent. This study is analytical observational with cross sectional design. 118 10th and 11th graders were taken as samples by proportional stratified random sampling technique. Statistical analysis showed that the factors significantly associate and become the risk factors are energy intake ( $p$-value 0.000; OR = 2.97); protein ( $p$ value 0.005; $O R=3.49) ;$ fat ( $p$-value 0.000; $O R=6.57) ;$ carbohydrates ( $p$-value 0.050; OR = 2.00); consumption of fast food ( $p$-value 0.000; OR = 4.41); physical activity ( $p$-value 0.007; OR = 3.08); pocket money ( $p$-value 0.032; OR = 2.38); and genetic ( $p$-value 0.001; OR =3.98). Adolescents with excessive macro nutrient intake, frequent consumption of fast food, low physical activity, high pocket money and a history of obese parents have a greater occurrence risk of obesity. Keywords: Risk Factors, Obesity, Adolescents
\end{abstract}


Faletehan Health Journal, 7 (3) (2020) 124-131

www. journal.Ippm-stikesfa.ac.id/ojs/index.php/FHJ

ISSN 2088-673X | 2597-8667

\section{Pendahuluan}

Indonesia sedang menghadapi kemungkinan meledaknya penderita obesitas. Proporsi berat badan lebih dan obesitas pada dewasa umur $>18$ tahun menunjukkan peningkatan yaitu $10,5 \%$ pada tahun 2007 dan $14,8 \%$ pada tahun 2013 serta 21,8\% pada tahun 2018 dengan indikator obesitas dewasa yaitu IMT $\geq 27$ (Depkes, 2008; Badan Penelitian dan Pengembangan Kesehatan, 2013; Badan Penelitian dan Pengembangan Kesehatan, 2018). Berdasarkan hasil Riset Kesehatan Dasar 2013 prevalensi obesitas pada remaja umur 16-18 tahun sebanyak $1,6 \%$, meningkat menjadi $4 \%$ pada tahun 2018. Sedangkan prevalensi obesitas pada remaja umur 16-18 tahun di Provinsi Sumatera Selatan sebesar 2\% (Badan Penelitian dan Pengembangan Kesehatan, 2018).

Pada remaja kejadian kegemukan dan obesitas merupakan masalah yang serius karena akan berlanjut hingga usia dewasa (Mokolensang dkk., 2016). Obesitas merupakan kondisi kelebihan berat badan akibat tertimbunnya lemak. Faktor penyebab obesitas pada remaja bersifat multifaktorial, diantaranya adalah asupan zat gizi makro berlebih, frekuensi konsumsi fast food yang sering, kurangnya aktivitas fisik, pola makan tidak seimbang, riwayat orang tua mengalami obesitas, serta tidak sarapan (Kurdanti dkk., 2015; Gozali \& Saraswati, 2017). Aktivitas fisik merupakan kunci utama keseimbangan energi yang menyumbang pengeluaran energi.

Obesitas terjadi pada kondisi asupan energi jauh melebihi penggunaan energi. Karbohidrat termasuk dalam zat gizi makro yang merupakan sumber energi utama bagi tubuh. Tingginya asupan karbohidrat dan asupan protein menjadi faktor risiko obesitas pada anak. Pada kondisi obesitas, tingginya asupan karbohidrat menyebabkan glukosa disimpan dalam bentuk trigliserida di jaringan adiposit. Asupan protein yang tinggi melebihi kebutuhan menyebabkan protein akan disimpan di jaringan adiposit. Lemak didalam tubuh diserap dalam bentuk asam lemak bebas dan disimpan dalam bentuk trigliserida di jaringan adiposit. Obesitas pada dasarnya disebabkan oleh kelebihan jaringan adiposit (Ayu dkk., 2018).

Konsumsi makanan dengan tinggi lemak dalam jangka waktu yang panjang dan tanpa ada aktivitas untuk pengeluaran energi dapat meningkatkan risiko terjadinya kegemukan.
Aktivitas fisik yang sangat ringan memiliki faktor risiko 9,5 kali lebih besar untuk menyebabkan terjadinya kegemukan dibandingkan dengan aktivitas fisik ringan (Praditasari \& Sumarmi, 2018).

Salah satu faktor yang berperan dalam timbulnya obesitas faktor genetik. Dalam waktu yang telah lama para ilmuwan mengamati bahwa anak-anak obesitas umumnya berasal dari keluarga dengan orang tua obesitas. Bila salah satu orang tua obesitas, $40-50 \%$ anak-anaknya akan berisiko obesitas, sedangkan bila kedua orang tua obesitas, $80 \%$ anak-anaknya akan berisiko obesitas (Misnadiarly, 2007). Hasil penelitian ditemukan terdapat hubungan obesitas orangtua terhadap kejadian obesitas pada remaja (Gozali \& Saraswati, 2017).

Obesitas menggambarkan akumulasi lemak pada adiposit yang dapat terjadi apabila asupan kalori dari konsumsi makanan melebihi kebutuhan metabolisme tubuh untuk pertumbuhan, perkembangan, dan aktivitas fisik. Obesitas pada awal kehidupan dapat menimbulkan peningkatan risiko obesitas pada masa dewasa serta menyebabkan peningkatan morbiditas dan mortalitas selama masa dewasa (Mistry \& Puthussery, 2015). Obesitas pada remaja meningkatkan risiko terjadinya penyakit seperti tekanan darah, kolesterol, tingkat trigliserida dan juga diabetes, sehingga menjadi faktor meningkatnya risiko stroke iskemik, jantung koroner, diabetes mellitus tipe 2 dan penyakit metabolisme lainnya (Rossouw et al., 2012).

Penelitian ini bertujuan untuk mengetahui faktor-faktor yang mempengaruhi kejadian obesitas pada remaja dengan menganalisis berbagai faktor penyebab yaitu faktor asupan makan (zat gizi makro, konsumsi fast food), faktor aktivitas fisik, faktor genetik, jumlah uang saku dan pengetahuan gizi.

\section{Metode Penelitian}

Jenis penelitian yang dilakukan merupakan penelitian bersifat observasional analitik dengan menggunakan desain cross sectional. Populasi dalam penelitian ini adalah siswa-siswi kelas $\mathrm{X}$ dan XI SMA Xaverius 3 dan Xaverius 2 Palembang. Proporsi siswa-siswi tiap kelas dihitung dengan teknik proporsional stratified random sampling. Berdasarkan hasil perhitungan besar sampel didapatkan jumlah sampel minimal 
kemudian ditambah $10 \%$, sehingga total menjadi 118 responden. Kriteria sampel adalah siswa yang bisa diajak berkomunikasi, bersedia menjadi responden, dan tidak dalam kondisi sakit.

Variabel bebas adalah asupan zat gizi makro (energi, protein, lemak dan karbohidrat), frekuensi konsumsi fast food, aktivitas fisik, jumlah uang saku, riwayat obesitas orangtua dan pengetahuan gizi, sedangkan variabel terikat adalah kejadian obesitas. Status obesitas adalah status gizi berdasarkan berat badan dan tinggi badan yang dilihat menggunakan indeks massa tubuh berdasarkan umur (IMT/U) berdasarkan z-score menggunakan WHO Anthroplus 2005 untuk kelompok umur 14-18 tahun, dengan kategori (obesitas $>2$ SD dan tidak obesitas $\leq 2 \mathrm{SD}$ ). Asupan zat gizi makro (energi, protein, lemak dan karbohidrat) adalah jumlah energi, protein, lemak dan karbohidrat yang dikonsumsi responden selama waktu tertentu dalam satuan g/hari berdasarkan hasil wawancara dengan menggunakan instrumen berupa Semi Quantitave Food Frequency Questionnaire $(S Q-F F Q)$ yang dikategorikan lebih $(>100 \%$ AKG) dan cukup ( $\leq$ $100 \%$ AKG) (Gibson, 2005).

Selanjutnya frekuensi konsumsi fast food dikategorikan sering apabila > $3 \mathrm{kali} / \mathrm{minggu}$, jarang apabila $\leq 3 \mathrm{kali} /$ minggu (Karmani dkk., 2018), data didapatkan berdasarkan wawancara menggunakan instrumen berupa Semi Quantitave Food Frequency Questionnaire (SQ-FFQ).

Penilaian aktivitas fisik menggunakan kuesioner IPAQ short form Metabolic Equivalent of Task (MET) merupakan satuan yang digunakan untuk memperkirakan dari energi yang dikeluarkan dari aktivitas fisik. Ada tiga kategori bedasarkan Automatic report of International Physical Activity Questionnaire (IPAQ) yang dapat dihitung dari Metabolic Equivalent of Task (MET) yaitu kategori berat, sedang dan ringan. Pengelompokan aktivitas fisik dalam penelitian ini berdasarkan pada kuesioner IPAQ yaitu ringan (MET < 600 MET-menit/minggu), aktivitas sedang (MET $\geq 600 \mathrm{MET}$-menit/minggu) dan aktivitas berat (MET 1500-3000 METmenit/minggu atau $\geq 3000 \mathrm{MET}$-menit/minggu). Pada penelitian ini dilakukan pengelompokan kategori aktifitas fisik menjadi 2 kategori yaitu aktivitas ringan dan berat. Pada penelitian ini aktivitas sedang hingga berat dikategorikan menjadi aktivitas berat (Christianto et al., 2018).
Jumlah uang saku rata-rata perhari perresponden didapatkan dengan proses wawancara, dengan kategori tinggi apabila jumlah uang saku $\geq$ rata-rata jumlah uang saku responden keseluruhan, dan rendah apabila < rata-rata jumlah uang saku keseluruhan.

Penilaian pengetahuan dilakukan dengan wawancara yang berisi mengenai pemahaman tentang obesitas dan kesehatan secara umum yang dimiliki oleh siswa berdasarkan kemampuan berfikir tentang obesitas dan bahan makanan yang baik. Didapat melalui hasil pengisian dari kuesioner. Jawaban yang benar dibagi jumlah soal dikali dengan 100\%. Sehingga dapat dikategorikan menjadi nilai baik bila skor $\geq 80 \%$ jawaban benar, dan nilai kurang apabila skor < $80 \%$.

Setelah pengukuran dan proses wawancara selesai, peneliti meminta kesediaan siswa untuk mengukur berat badan dan tinggi badan orang tuanya di rumah. Setelah data berat badan dan tinggi badan orang tua terkumpul, selanjutnya peneliti menghitung indeks massa tubuh orang tua masing-masing responden. Kemudian dikategorikan menjadi gemuk, apabila ada salah satu orang tua yang dengan status IMT $\geq 30$, dan normal apabila tidak ada salah satu orang tua dengan IMT $<30$.

Analisis data menggunakan analisis univariat Chi-Square dengan CI:95\%, dan untuk melihat ukuran hubungan variabel menggunakan OR. Rekomendasi persetujuan etik penelitian yaitu No: 653/KEPK-PTKMKS/XI/2017.

\section{Hasil dan Pembahasan}

Sebagian besar umur responden pada penelitian ini yaitu 15 tahun sebanyak 53 orang (44.9\%) dan siswa terbanyak yang menjadi responden adalah laki-laki (60.2\%). Responden yang memiliki status obesitas mencapai $33.1 \%$. Asupan zat gizi makro (energi, protein, lemak dan karbohidrat) dengan kategori lebih rata-rata mencapai $34 \%$. Hal ini menunjukkan bahwa siswa pada umur remaja kelebihan asupan zat gizi terumata makro cukup tinggi. Hal ini ditunjang dengan konsumsi fast food yang sering sebesar $63.6 \%$ dan aktifitas fisik yang ringan sebesar $64.4 \%$. Pengetahuan mengenai gizi dan obesitas didapatkan 35.6\% siswa dengan kategori kurang. 
Faletehan Health Journal, 7 (3) (2020) 124-131

www. journal.Ippm-stikesfa.ac.id/ojs/index.php/FHJ

ISSN 2088-673X | 2597-8667

Tabel 1. Distribusi Frekuensi Karakteristik Variabel Penelitian

\begin{tabular}{|c|c|c|}
\hline Variabel & $\mathbf{n}$ & $\%$ \\
\hline \multicolumn{3}{|l|}{ Usia } \\
\hline 14 tahun & 20 & 16.9 \\
\hline 15 tahun & 53 & 44.9 \\
\hline 16 tahun & 40 & 33.9 \\
\hline 17 tahun & 5 & 4.2 \\
\hline \multicolumn{3}{|l|}{ Jenis Kelamin } \\
\hline Laki-laki & 71 & 60.2 \\
\hline Perempuan & 47 & 39.8 \\
\hline \multicolumn{3}{|l|}{ Status Obesitas } \\
\hline Obesitas & 39 & 33.1 \\
\hline Tidak Obesitas & 79 & 66.9 \\
\hline \multicolumn{3}{|l|}{ Asupan Energi } \\
\hline Lebih & 36 & 30.5 \\
\hline Cukup & 82 & 69.5 \\
\hline \multicolumn{3}{|l|}{ Asupan Protein } \\
\hline Lebih & 27 & 22.9 \\
\hline Cukup & 91 & 77.1 \\
\hline \multicolumn{3}{|l|}{ Asupan Lemak } \\
\hline Lebih & 35 & 29.7 \\
\hline Cukup & 83 & 70.3 \\
\hline \multicolumn{3}{|c|}{ Asupan Karbohidrat } \\
\hline Lebih & 56 & 47.5 \\
\hline Cukup & 62 & 52.5 \\
\hline \multicolumn{3}{|c|}{ Konsumsi fast food } \\
\hline Sering & 64 & 54.2 \\
\hline Jarang & 54 & 45.8 \\
\hline \multicolumn{3}{|l|}{ Aktivitas Fisik } \\
\hline Ringan & 71 & 60.2 \\
\hline Berat & 47 & 39.8 \\
\hline \multicolumn{3}{|l|}{ Uang saku } \\
\hline Tinggi & 66 & 55.9 \\
\hline Rendah & 52 & 44.1 \\
\hline \multicolumn{3}{|l|}{ Keturunan (gen) } \\
\hline Gemuk & 66 & 55.9 \\
\hline Tidak Gemuk & 52 & 44.1 \\
\hline \multicolumn{3}{|l|}{ Pengetahuan Gizi } \\
\hline Kurang & 42 & 35.6 \\
\hline Baik & 76 & 64.4 \\
\hline
\end{tabular}

Hasil analisis didapatkan bahwa faktor yang secara bermakna berhubungan dan menjadi faktor risiko terjadinya obesitas pada remaja adalah asupan zat gizi makro (energi, protein, lemak, dan karbohidrat), konsumsi fast food, aktivitas fisik, uang saku dan keturunan (gen) (Tabel 2).

Remaja dengan asupan energi lebih berisiko 2,97 kali lebih besar mengalami obesitas dibandingkan remaja dengan asupan energi cukup $(\mathrm{p}=0.000)$. Remaja yang beriko obesitas memiliki rerata asupan energi sebesar 3580,5 kkal dibandingkan rerata asupan yang tidak obesitas yaitu 3125, 2 kkal. Demikian juga untuk asupan protein, lemak dan karbohidrat yang menunjukkan bahwa sebagian besar remaja yang obesitas memiliki asupan berlebih, terutama untuk asupan lemak berlebih mencapai $62.9 \%$, sehingga berisiko 6.5 kali lebih besar mengalami obesitas.

Menurut Almatsier (2009), obesitas terjadi akibat ketidakseimbangan antara asupan energi yang masuk ke dalam tubuh dengan energi yang keluar, sehingga mengakibatkan terjadinya berat badan lebih atau obesitas pada seseorang. Sejalan dengan hasil penelitian oleh Kurdanti dkk., (2015) yang menyatakan faktor risiko terjadinya obesitas pada remaja adalah asupan energi $(\mathrm{p}=0,000)$ dengan risiko 4,69 kali lebih besar dibandingkan dengan yang tidak obesitas.

Berdasarkan hasil recall pada responden didapatkan bahwa sumber protein yang sering dikonsumsi oleh siswa adalah daging, ayam goreng, telur, cilok dan susu. Asupan protein secara langsung memiliki hubungan dengan obesitas, apabila seseorang mengkonsumsi protein makanan lebih besar dari yang digunakan jaringannya, maka sebagian besar jumlah protein yang berlebih ini akan disimpan dalam bentuk lemak. Menurut Almatsier (2009), makanan yang tinggi protein biasanya tinggi lemak sehingga dapat menyebabkan obesitas.

Apabila asupan lemak yang melebihi kebutuhan dalam jangka waktu yang lama dapat memicu timbulnya obesitas. Makanan tinggi lemak mempunyai rasa yang lezat dan kemampuan mengenyangkan yang rendah, sehingga dapat dikonsumsi secara berlebihan. Lemak didalam mempunyai kapasitas penyimpanan yang tidak terbatas. Jika kelebihan asupan lemak tidak diiringi peningkatan oksidasi lemak sehingga sekitar $96 \%$ lemak akan disimpan dalam tubuh.

Dari 19 siswa obesitas yang asupan lemaknya berlebih, rata-rata dari mereka kebanyakan mengkonsumsi sumber lemak berasal dari makanan yang diolah menggunakan minyak maupun margarin. Jenis makanan yang sering dikonsumsi seperti goreng-gorengan, ayam goreng, dan kentang goreng. Marmi (2013) menyatakan bahwa pada anak remaja, jajanan atau snack berkontribusi $30 \%$ atau lebih dari total asupan kalori remaja setiap hari. Jajanan ini cenderung mengandung tinggi lemak, gula dan 
natrium sehingga dapat meningkatkan risiko kegemukan dan karies gigi.

Obesitas terjadi karena penimbunan lemak didalam tubuh, lemak ini kemudian dibawa ke selsel lemak yang dapat menyimpan lemak dalam jumlah tidak terbatas sehingga meningkatakan resiko terjadinya berbagai gangguan kesehatan, salah satunya adalah obesitas (Almatsier, 2009).

Berdasarkan hasil recall pada 23 siswa obesitas yang asupan karbohidratnya lebih, ratarata dari mereka kebanyakan mengkonsumsi minuman botolan dan kalengan serta sumber karbohidrat kompleks seperti nasi putih, mie dan roti. Karbohidrat termasuk dalam zat gizi makro yang merupakan sumber energi utama bagi tubuh. Jika asupan karbohidrat melebihi kebutuhan maka sel dapat mengubah karbohidrat menjadi lemak. Perubahan proses tersebut terjadi didalam hati. Lemak tersebut kemudian dibawa ke sel-sel lemak yang dapat menyimpan lemak dalam jumlah yang tidak terbatas sehingga dapat menyebabkan kenaikan berat badan. Hasil penelitian ini sejalan dengan Kurdanti dkk., (2015) yang menyatakan bahawa salah satu faktor yang mempengaruhi kejadian obesitas adalah asupan karbohidrat $(\mathrm{p}=0,004)$. Tingginya konsumsi karbohidrat disebabkan mengkonsumsi makanan tinggi karbohidrat pada jam istirahat (jajan) seperti nasi goreng, cilok, batagor, mie ayam, bakso dan siomay.

Persentase frekuensi fast food dengan kategori sering lebih banyak ditemukan pada remaja berisiko obesitas dibandingkan dengan kategori jarang (46.9\% vs $16.7 \%$ ). Konsumsi fast food yang semakin sering berisiko 4.4 kali mengalami obesitas dibandingkan yang jarang mengkonsumsi fast food. Berdasarkan hasil data pada kuesioner form FFQ pada siswa yang obesitas didapatkan frekuensi fast food yang sering dikonsumsi adalah cilok, bakso bakar, fried chicken, burger, mie. Rata-rata siswa mengkonsumsi fast food pada saat di luar rumah yaitu pada jam istirahat sekolah atau jam pulang sekolah.

Peningkatan prevalensi obesitas pada remaja disertai pergeseran pola makan yang komposisinya mengandung tinggi lemak, kolesterol, tetapi rendah serat seperti konsumsi fast food dan soft drink. Salah satu faktor risiko terhadap munculnya obesitas pada remaja adalah ketidakseimbangan asupan gizi. Hasil penelitian Rafiony dkk., (2015) menyatakan bahwa ada hubungan antara asupan frekuensi konsumsi fast food total dan fast food lokal dengan obesitas ( $\mathrm{p}=$ 0,030 dan 0,003). Penelitian Mohammadbeigi et al., (2018) menemukan 72,4\% siswa mengkonsumsi setidaknya satu jenis makanan fast food dalam beberapa bulan terakhir termasuk sandwich $44,4 \%$, pizza $39,7 \%$, dan ayam goreng $13,8 \%$. Konsumsi makanan cepat saji merupakan tren yang muncul dikalangan remaja di seluruh dunia. Hasil penelitian ditemukan bahwa $64 \%$ siswa sering mengkonsumsi makanan cepat saji (>3 hari/minggu). Terdapat hubungan yang signifikan antara konsumsi fast food dengan prevalensi obesitas $(p=0,05)$. Cita rasa, kelezatan, kepuasan dan kemudahan untuk mendapatkannya, menjadi alasan siswa mengkonsumsi fast food (Banik et al., 2020; Ali \& Nuryani, 2018).

Aktivitas fisik terlihat pada remaja yang berisiko obesitas sebagian besar rendah $(42,3 \%)$, aktivitas fisik yang rendah berisiko 3 kali mengalami obesitas dibandingkan dengan aktivitas berat. Sebagian besar remaja berpendapat bahwa aktivitas fisik cukup dengan olahraga di sekolah saja. Mereka kurang termotivasi untuk melakukan aktivitas fisik dalam bentuk olahraga dikarenakan tidak menguasai satu bidang olah raga ataupun jenis-jenis olahraga yang tidak dipelajari di sekolah. Berdasarkan pemahaman dan pengalaman mereka, tidak ada satupun remaja yang menyoroti bahwa pentingnya aktivitas fisik dalam kehidupan yang lebih aktif (Sundar et al., 2018). Berkurangnya aktivitas fisik dan peningkatan penggunaan media menjadi penyebab semakin meningkatnya jumlah obesitas pada remaja (Wulff \& Wagner, 2018).

Kategori pengetahuan gizi tidak berhubungan secara bermakna dengan risiko obesitas pada remaja, hal ini dapat disebabkan kurangnya pengetahuan gizi yang diterima oleh remaja baik berisiko obesitas maupun tidak obesitas. Sehingga hal ini perlu menjadi perhatian. Sejalan dengan penelitian yang dilakukan oleh Dewi \& Kartini (2017) bahwa tidak terdapat hubungan bermakna antara pengetahuan gizi dengan kejadian obesitas. Pengetahuan tentang pemilihan makanan sangat diperlukan oleh para remaja guna menghindari konsekuensi terjadinya obesitas pada usia dewasa nantinya (Xu \& Xue, 2016). 
Faletehan Health Journal, 7 (3) (2020) 124-131

www. journal.Ippm-stikesfa.ac.id/ojs/index.php/FHJ

ISSN 2088-673X | 2597-8667

Tabel 2. Faktor Risiko yang Berpengaruh terhadap Kejadian Obesitas pada Remaja

\begin{tabular}{|c|c|c|c|c|c|c|}
\hline \multirow{3}{*}{ Variabel } & \multicolumn{4}{|c|}{ Status Obesitas } & \multirow{3}{*}{$\begin{array}{c}\text { OR } \\
(95 \% \mathrm{CI})\end{array}$} & \multirow{3}{*}{$p$ value } \\
\hline & \multicolumn{2}{|c|}{ Obesitas } & \multicolumn{2}{|c|}{ Tidak Obesitas } & & \\
\hline & $\mathbf{n}$ & $\%$ & $\mathrm{n}$ & $\%$ & & \\
\hline \multicolumn{7}{|l|}{ Asupan Energi } \\
\hline Lebih & 21 & 58.3 & 15 & 41.7 & \multirow{2}{*}{$\begin{array}{c}2.978 \\
(2.140-11.577)\end{array}$} & \multirow[t]{2}{*}{0.000} \\
\hline Cukup & 18 & 22.0 & 64 & 78.0 & & \\
\hline \multicolumn{6}{|l|}{ Asupan Protein } & \multirow{3}{*}{0.005} \\
\hline Lebih & 15 & 55.6 & 12 & 44.4 & 3.490 & \\
\hline Cukup & 24 & 26.4 & 67 & 73.6 & $(1.432-8.505)$ & \\
\hline \multicolumn{6}{|l|}{ Asupan Lemak } & \multirow{3}{*}{0.000} \\
\hline Lebih & 22 & 62.9 & 13 & 37.1 & 6.570 & \\
\hline Cukup & 17 & 20.5 & 66 & 79.5 & $(2.757-15.659)$ & \\
\hline \multicolumn{6}{|c|}{ Asupan Karbohidrat } & \multirow{3}{*}{0.050} \\
\hline Lebih & 23 & 41.1 & 33 & 58.9 & 2.004 & \\
\hline Cukup & 16 & 25.8 & 46 & 74.2 & $(0.919-4.367)$ & \\
\hline \multicolumn{6}{|c|}{ Konsumsi Fast Food } & \multirow{3}{*}{0.000} \\
\hline Sering & 30 & 46.9 & 34 & 53.1 & 4.412 & \\
\hline Jarang & 9 & 16.7 & 45 & 83.3 & $(1.852-10.508)$ & \\
\hline \multicolumn{6}{|l|}{ Aktivitas Fisik } & \multirow{3}{*}{0.007} \\
\hline Ringan & 30 & 42.3 & 41 & 57.7 & 3.089 & \\
\hline Berat & 9 & 19.1 & 38 & 80.9 & $(1.300-7.344)$ & \\
\hline \multicolumn{6}{|l|}{ Uang Saku } & \multirow{3}{*}{0.032} \\
\hline Tinggi & 27 & 40.9 & 39 & 59.1 & 2.308 & \\
\hline Rendah & 12 & 23.1 & 40 & 76.9 & $(1.026-5.190)$ & \\
\hline \multicolumn{6}{|l|}{ Gen } & \multirow{3}{*}{0.001} \\
\hline Gemuk & 30 & 45.5 & 36 & 54.5 & 3.981 & \\
\hline Tidak Gemuk & 9 & 17.3 & 43 & 82.7 & $(1.674-9.471)$ & \\
\hline \multicolumn{6}{|l|}{ Pengetahuan Gizi } & \multirow{3}{*}{0.202} \\
\hline Kurang & 17 & 40.5 & 25 & 59.5 & 1.669 & \\
\hline Baik & 22 & 28.9 & 54 & 71.1 & $(0.757-3.681)$ & \\
\hline
\end{tabular}

Uang saku dengan kategori tinggi berisiko 2 kali menderita obesitas. Siswa dengan jumlah uang saku tinggi cenderung dapat memilih jenis makanan yang dibeli dan yang diinginkannya, sedangkan siswa dengan jumlah uang saku rendah tidak dapat leluasa memilih jenis makanan, mereka cenderung memilih makanan yang murah dan mengenyangkan seperti makanan jenis gorengan dan cepat saji, tanpa memperhatikan apakah makanan tersebut mengandung gizi seimbang atau tidak. Hasil penelitian yang dilakukan oleh Simbolon dkk., (2018), salah satu faktor yang mempengaruhi perubahan berat badan remaja setelah diberikan edukasi gizi adalah uang saku $(p=0,44)$. Orangtua diharapkan untuk memanejemen uang saku anak sehingga anak mampu meminimalisisr pembelian jajan yang dapat mengakibatkan obesitas.
Keturunan (gen) dari orang tua yang gemuk berisiko 3.9 kali menderita obesitas. Dari hasil penelitian didapatkan ada beberapa siswa yang mengalami obesitas ditemukan bahwa kedua orang tuanya memiliki berat badan normal, hal tersebut disebabkan oleh pola makan yang tidak teratur, suka mengkonsumsi makanan siap saji (fast food) dan kurang melakukan olahraga (aktivitas fisik). Seperti yang diungkapkan oleh Soetjiningsih (2010) bahwa kalau salah satu orang tuanya yang obesitas maka anaknya mempunyai resiko 30\%-40\% menjadi obesitas. Namun, risikonya meningkat menjadi $70 \%-80 \%$ jika kedua orang tuanya obesitas. Hasil penelitian ini sejalan dengan penelitian yang mengatakan bahwa riwayat obesitas pada orang tua meningkatkan risiko obesitas 2,016 kali pada remaja dan terdapat hubungan yang bermakna antara riwayat 
obesitas orang tua dengan kejadian obesitas pada remaja (Ali \& Nuryani, 2018).

\section{Simpulan}

Remaja yang memiliki asupan zat gizi makro berlebih (energi, protein, lemak dan karbohidrat), konsumsi fast food yang sering, aktivitas fisik ringan, uang saku yang tinggi dan memiliki riwayat orang tua dengan status gemuk, berisiko lebih terhadap terjadinya obesitas.

\section{Referensi}

Ali, R., \& Nuryani. (2018). Sosial ekonomi, konsumsi. Media Gizi Indonesia, 13(2018), 123-132.

https://doi.org/10.20473/mgi.v13i2.123

Almatsier, S. (2009). Prinsip Ilmu Gizi Dasar. Jakarta : PT Gramedia Pustaka Utama.

Ayu, D., Primashanti, D., \& Sidiartha, I. G. L. (2018). Protein Dan Lemak Dengan Angka Kecukupan Gizi Pada Anak Obesitas. Medicina, $\quad 49(2), \quad$ 173-178. https://doi.org/10.15562/medi.v49i2.66

Badan Penelitian dan Pengembangan Kesehatan. (2013). Riset Kesehatan Dasar 2013. Kementerian Kesehatan Republik Indonesia.

Badan Penelitian dan Pengembangan Kesehatan. (2018). Laporan Nasional Riskesdas 2018. Kementerian Kesehatan Republik Indonesia.

Banik, R., Naher, S., Pervez, S., \& Hossain, M. M. (2020). Fast food consumption and obesity among urban college going adolescents in Bangladesh: A cross-sectional study. Obesity Medicine, 17(November 2019), 100161. https://doi.org/10.1016/j.obmed.2019.100161

Christianto, D. A., Barus, A. M. B., Dewita, A. N., Ramadhanti, Puspitasari, A. R., Pramudito, P. A., \& Fenty. (2018). Hubungan Aktivitas Fisik Terhadap Kejadian Obesitas Berdasarkan Indeks Massa Tubuh Di Desa Banjaroyo Kulon Progo Daerah Istimewa Yogyakarta. Berkala Ilmiah Kedokteran Duta Wacana, 3(2), 78-88.

Depkes. (2008). Laporan Nasional Riskesdas 2007. Badan Penelitian Dan Pengembangan Kesehatan Departemen Kesehatan, Republik Indonesia Desember 2008, 1-384. http://kesga.kemkes.go.id/images/pedoman/ Riskesdas 2007 Nasional.pdf

Dewi.P.L.P, \& Kartini, A. (2017). Hubungan Pengetahuan Gizi, Aktivitas Fisik, Asupan
Energi dan Asupan Lemak dengan Kejadian Obesitas pada Remaja Sekolah Menengah Pertama. Journal of Nutrition College, 6(3), 257-261.

Gibson, R. S. (2005). Principles of Nutritional Assessment Google Books. Oxford University Press.

Gozali, T. O., \& Saraswati, M. R. (2017). Hubungan Obesitas Pada Orangtua Dengan Terjadinya Obesitas Pada Anak Remaja SMA Di Kota Denpasar, Provinsi Bali. Jurnal Penyakit Dalam Udayana, 1(1), 22 29. https://doi.org/10.36216/jpd.v1i1.11

Karmani, N. N. K., Sidiartha, I. G. L., Suparyatha, I. B., \& Pratiwi, I. G. A. P. E. (2018). Prevalens Dan Faktor Risiko Overweight/Obesitas Pada Anak Dan Remaja Vegetarian Di Bali. E-Jurnal Medika, 7(12), 1-7.

Kurdanti, W., Suryani, I., Syamsiatun, N. H., Siwi, L. P., Adityanti, M. M., Mustikaningsih, D., \& Sholihah, K. I. (2015). Faktor-faktor yang mempengaruhi kejadian obesitas pada remaja. Jurnal Gizi Klinik Indonesia, 11 11(4), 179. https://doi.org/10.22146/ijcn.22900

Marmi. (2013). Gizi dalam Kesehatan Reproduksi. Yogyakarta: Pustaka Pelajar.

Misnadiarly. (2007). Obesitas sebagai Faktor Risiko beberapa Penyakit. Jakarta: Penerbit Yayasan Obor Indonesia.

Mistry, S. K., \& Puthussery, S. (2015). Risk factors of overweight and obesity in childhood and adolescence in South Asian countries: A systematic review of the evidence. Public Health, 129(3), 200-209. https://doi.org/10.1016/j.puhe.2014.12.004

Mohammadbeigi, A., Asgarian, A., Moshir, E., Heidari, H., Afrashteh, S., Khazaei, S., \& Ansari, H. (2018). Fast food consumption and overweight/obesity prevalence in students and its association with general and abdominal obesity. Journal of Preventive Medicine and Hygiene, 59(3), E236-E240. https://doi.org/10.15167/24214248/jpmh2018.59.3.830

Mokolensang, O. G., Manampiring, A. E., \& . F. (2016). Hubungan Pola Makan Dan Obesitas Pada Remaja Di Kota Bitung. Jurnal EBiomedik, $4(1)$. https://doi.org/10.35790/ebm.4.1.2016.10848 Praditasari, J. A., \& Sumarmi, S. (2018). Asupan 
Faletehan Health Journal, 7 (3) (2020) 124-131

www. journal.Ippm-stikesfa.ac.id/ojs/index.php/FHJ

Lemak, Aktivitas Fisik Dan Kegemukan Pada Remaja Putri Di Smp Bina Insani Surabaya Fat Intake, Physical Activity and Obesity among Adolescent Girls in SMP Bina Insani Surabaya. Media Gizi Indonesia, 13 No. 2(2018), 117-122. https://doi.org/10.20473/mgi.v13i2.117-122

Rafiony, A., Purba, M. B., \& Pramantara, I. D. P. (2015). Konsumsi fast food dan soft drink sebagai faktor risiko obesitas pada remaja. Jurnal Gizi Klinik Indonesia, 11(4), 170. https://doi.org/10.22146/ijen.23311

Rossouw, H. A., Grant, C. C., \& Viljoen, M. (2012). Overweight and obesity in children and adolescents: The South African problem. South African Journal of Science, 108(5-6). https://doi.org/10.4102/sajs.v108i5/6.907

Simbolon, D., Tafrieani, W., \& Dahrizal, D. (2018). Edukasi Gizi dan Perubahan Berat Badan Remaja Overweight dan Obesitas. Jurnal Kesehatan, 9(2), 289. https://doi.org/10.26630/jk.v9i2.841
Soetjiningsih. (2010). Buku Ajar Tumbuh Kembang Remaja dan Permasalahannya. Jakarta: Sagung Seto.

Sundar, T. K. B., Løndal, K., Lagerløv, P., Glavin, K., \& Helseth, S. (2018). Erratum: Correction to: Overweight adolescents' views on physical activity - experiences of participants in an internet-based intervention: a qualitative study. BMC Public Health, 18(1), 622. https://doi.org/10.1186/s12889018-5546-y

Wulff, H., \& Wagner, P. (2018). Media Use and Physical Activity Behaviour of Adolescent Participants in Obesity Therapy: Impact Analysis of Selected Socio-Demographic Factors. Obesity Facts, 11(4), 307-317. https://doi.org/10.1159/000490178

Xu, S., \& Xue, Y. (2016). Protein intake and obesity in young adolescents (Review). Experimental and Therapeutic Medicine, 11(5), 1545-1549. https://doi.org/10.3892/etm.2016.3137 